\title{
Molecular characterization of Bacillus thuringiensis using rep-PCR
}

Rosane Bezerra da Silva ${ }^{1}$ and Fernando Hercos Valicente ${ }^{2^{*}}$

\begin{abstract}
The genetic divergence of 65 strains of Bacillus thuringiensis (Bt) was determined using Rep-PCR. Based on the repetitive sequences the BOX primer was the most informative with 26 fragments, followed by ERIC (19) and REP (10), generating a total of 55 fragments. The dendogram shows that ten groups were formed when $45 \%$ was the average distance of the population: group 1 with $41,5 \%$ of the isolates, $33,8 \%$ of the isolates were distributed in other groups and $24,6 \%$ did not formed distinct group. 53,2\% of the isolates from Embrapa are in the group 1, and 29,8\% of the isolates are distributed in other groups. Bt strains from USDA and Institute Pasteur showed more variability.
\end{abstract}

Keywords: REP-PCR; Genetic divergence; Bacillus thuringiensis; Repetitive sequences

\section{Introduction}

Spodoptera frugiperda (Smith) is responsible for significant losses in maize yield in Brazil. Its control is mainly achieved using chemical insecticides. However, biological control using Bacillus thuringiensis Berliner (Bt), and the production of genetically modified plants with insect resistance genes are promising alternatives to control these insect (Valicente and Barreto, 2003).

B. thuringiensis (Bt) is a gram-positive bacterium that produces protein crystalline inclusions called Cry proteins during the stationary phase encoded by different $c r y$ genes (Yamamoto \& Dean, 2000). B. thuringiensis can be found in different substrates such as soil, water, plant surfaces, dead insects, grain dust, spider webs and stored grain (Glare \& O'Callaghan 2000; Valicente \& Barreto 2003; and Miralles \& Peres 2004). This bacterium also shows a high genetic variability and is widely distributed in nature (Vilas-Boas et al. 2002). The genetic variability between different isolates has been studied using the polymerase chain reaction (PCR) with positive results (Shangkuan et al. 2001; Lima et al. 2002).

However, Repetitive Element Polymorphism REP-PCR fingerprinting has become a frequent method to discriminate bacteria species analyzing the distribution of repetitive DNA sequences in several prokaryotic genome (Versalovic

\footnotetext{
* Correspondence: fernando.valicente@embrapa.br

${ }^{2}$ Department of Biological control, Embrapa Maize and Sorghum research,

Sete Lagoas, Minas Gerais, Brazil

Full list of author information is available at the end of the article
}

et al. 1991). It is reliable, reproducible and simple, and of rapid implementation, in addition to high efficiency with the discrimination of microorganisms, even among populations of the same species (Versalovic et al. 1994; Rademaker \& De Bruijin 1997; Louws et al. 1999).

REP-PCR is based on the observation that outwardly facing oligonucleotide primers, complementary to interspersed repeated sequences, enable the amplification of differently sized DNA fragments, consisting of sequences lying between these elements (Versalovic et al. 1994). Multiple amplicons of different sizes can be resolved by electrophoresis, establishing DNA fingerprint specific patterns for bacteria strains (Rademaker \& De Bruijin 1997). Several of these interspersed repetitive elements are conserved in diverse genera of bacteria and, therefore, enable single primer sets to be used for DNA fingerprinting in many different microorganisms (Versalovic et al. 1994; Rademaker \& De Bruijin 1997). Moreover, it is not necessary prior knowledge of the genomic sequence of a species, with an initial selection of primers, to have this approach generates results in a short period of time (Shangkuan et al. 2001; Lima et al. 2002).

The Palindromic Units (PU) Repetitive Extragenic Palindromes (REP) constitutes the characterized family of bacterial repetitive sequences. PU are present in about 500-1000 copies in the chromosome of Escherichia coli and of Salmonella typhimurium. PU sequences consist of a 35-40 bp inverted repeat and are found in clusters in which successive copies (up to six) are arranged in 
alternate orientation (Higgins et al. 1982; Gilson et al. 1984; Martin et al. 1992).

A second family of repetitive elements, called IRU (Intergenic Repeat Units) or ERIC (Enterobacterial Repetitive Intergenic Consensus), has been described (Versalovic et al. 1991). IRU are 124-127 bp long and are present in about 30-50 copies in E. coli and 150 copies in S. typhimurium. Although IRU resembles PU in several features, the nucleotide sequence is entirely different and PU IRU, appear to occur singly. Both PU and IRU families are similarly located in non-coding, probably transcribed, regions of the chromosome. The consensus BOX element is constituted, from $5^{\prime}$ to $3^{\prime}$, of three subunits, boxA (59 bp), boxB ( $45 \mathrm{bp}$ ), and boxC (50 bp), and it is $154 \mathrm{bp}$ long present in about 25 fragments of the S. pneumoniae chromosome (Stern et al. 1984; Sharples \& Lloyd 1990; Versalovic et al. 1991; Martin et al. 1992; Shuhaimi et al. 2001).

Versalovic et al. (1991) outlined pairs of primer sequences corresponding to ERIC, REP and BOX palidromic sequences. However, little is known about the efficiency of these primers to give information about $B$. thuringiensis isolates. This study aimed to estimate the genetic diversity of 65 strains of $B$. thuringiensis based on ERIC, REP and $\mathrm{BOX}$ sequences, and identifies possible groupings related subspecies.

\section{Materials and methods}

Of a total of 65 B. thuringiensis strains (Table 1), 26 were identified as: nine kindly provided by the USDA (United States Department of Agriculture), 9 kindly provided by the Institute Pasteur, 8 from Embrapa Maize and Sorghum Bt Bank, and 39 strains with no subspecies information also from Embrapa's collection. All strains have been previously tested against fall armyworm, S. frugiperda (Lepidoptera: Noctuidae J.E. Smith) (Valicente \& Fonseca 2004; Valicente \& Barreto 2003). These strains are stored in glycerol at $-20^{\circ} \mathrm{C}$.

\section{DNA extraction and PCR conditions}

Genomic DNA from Bt strains was isolated and purified according to Shuhaimi et al. (2001).

ERIC and BOX primers:

The amplification reactions were conducted using 30 ng DNA, $3 \mathrm{mM} \mathrm{MgCl2}, 20 \mathrm{mM}$ Tris $\mathrm{pH}$ 8.0, $50 \mathrm{mM}$ $\mathrm{KCl}, 250 \mu \mathrm{M}$ of dNTP, $10 \mu \mathrm{M}$ of each primer and two units of Taq DNA polymerase, in a final volume of $20 \mu \mathrm{l}$.

The sequences of primers designed by Versalovic et al. (1994) were:

\section{ERIC 1 5' - ATGTAAGCTCCTGGGGATTCAC-3' ERIC 2 5'- AAGTAAGTGACTGGGGTGAGCG-3' BOX 5'-CTACGGCAAGGCGACGCTGACG-3}

The amplifications were carried out in a thermocycler Mastercycler (Eppendorf, Hanburg, Germany) using the following program: 40 cycles at $94^{\circ} \mathrm{C}$ for $1 \mathrm{~min}, 50^{\circ} \mathrm{C}$ for $1 \mathrm{~min}$ and $72^{\circ} \mathrm{C}$ for $2 \mathrm{~min}$. An extension step at $72^{\circ} \mathrm{C}$ for 7 min was added.

The amplified fragments were separated in $1.5 \%$ agarose gel, in TAE buffer (0.1 M EDTA pH 8.0, 0.04 M TRIS $\mathrm{pH}$ 8.0, and $0.02 \mathrm{M}$ acetic acid), under electrophoresis at $80 \mathrm{~V}$ for approximately 3 hours. The amplification products were analyzed under UV light using a Gel Logic 200 Imaging System photo documentation system.

REP primers:

The amplification reactions were conducted as follows: $50 \mathrm{ng}$ of DNA, $3 \mathrm{mM} \mathrm{MgCl}$, $20 \mathrm{mM}$ Tris, $50 \mathrm{mM} \mathrm{KCl}$, $250 \mu \mathrm{M}$ of dNTP, $1 \mu \mathrm{M}$ of each primer and two units of Taq DNA polymerase, with a final volume of $20 \mu \mathrm{L}$.

The sequences of primers designed by Versalovic et al. (1994) were:

\section{REP1 5'-IIIICGICGICATCIGGC-3' REP2 5'-ICGICTTATCIGGCCTAC-3'}

REP amplification used the following program: $5 \mathrm{~min}$ at $94^{\circ} \mathrm{C}$, followed by 41 cycles at $94^{\circ} \mathrm{C}$ for $1 \mathrm{~min}, 45^{\circ} \mathrm{C}$ for $1 \mathrm{~min}$, and $72^{\circ} \mathrm{C}$ for $2 \mathrm{~min}$. A final extension step was at $72^{\circ} \mathrm{C}$ for 7 min was added.

The amplified fragments were separated in $1.2 \%$ agarose gel in TAE buffer (0.1 M EDTA pH 8.0, 0.04 M TRIS $\mathrm{pH}$ 8.0, and $0.02 \mathrm{M}$ acetic acid) and held the race of $80 \mathrm{~V}$ for approximately 3 hours. The amplification of the products were analyzed under UV transilluminator, and filed using a Gel Logic 200 Imaging System photo documentation system.

\section{Evaluation of molecular data}

The amplification products were transformed into binary matrixes where 1 (one) was attributed to the presence of the band and 0 (zero) for absence.

\section{Analysis of genetic diversity}

The genetic relationships between strains were evaluated using a matrix of genetic distances constructed using the complement of the Jaccard similarity coefficient (CSJ), that does not consider negative similarities and the absence of the product (Cruz \& Carneiro, 2006).

From estimates of the dissimilarities, the strains were grouped using hierarchical UPGMA method (Unweighted Pair-Group Mean Average) with the test of bootstrap (1000 times) to evaluate the consistency of the group (Efron \& Tibshirani, 1993). A second analysis was performed using the pooling method of Tocher. All these tests were performed using the Genes program (Cruz, 2001). 
Table 1 Bacillus thuringiensis serovars used in this study

\begin{tabular}{|c|c|c|c|c|c|c|c|}
\hline $\mathbf{N}^{\circ}$ & Strain identification & Mortality (\%) & Origin & $\mathrm{N}^{\circ}$ & Strain identification & Mortality (\%) & Origin \\
\hline 1 & HD-4 Bt alesti & 6.8 & USA & 34 & $1109 \mathrm{~N}$ & 100 & Goiás \\
\hline 2 & 348B - Bt alesti & 100 & Paraná & 35 & $1145 B$ & 100 & Goiás \\
\hline 3 & T-07 Bt aizawai & 80.8 & France & 36 & $1145 C$ & 100 & Goiás \\
\hline 4 & HD-11 Bt aizawai & 7.8 & USA & 37 & $1148 \mathrm{~F}$ & 100 & Goiás \\
\hline 5 & 462A-Bt galleriae & 100 & Paraná & 38 & $1132 \mathrm{E}$ & 100 & Goiás \\
\hline 6 & 474 - Bt galleriae & 100 & Paraná & 39 & $1135 B$ & 100 & Goiás \\
\hline 7 & $348 \mathrm{~L}-$ - Bt galleriae & 100 & Paraná & 40 & $1136 \mathrm{~B}$ & 100 & Goiás \\
\hline 8 & HD-29 Bt galleriare & 12.8 & USA & 41 & $1139 \mathrm{~K}$ & 100 & Goiás \\
\hline 9 & $344-B t$ tolworthi & 100 & Paraná & 42 & BTLM & 100 & Goiás \\
\hline 10 & T-09 Bt tolworthi & 100 & France & 43 & 1644 & 100 & Paraná \\
\hline 11 & $426-B t$ tolworthi & 100 & Ceará & 44 & 1641 & 100 & Paraná \\
\hline 12 & $461 \mathrm{~A}-\mathrm{Bt}$ tolworthi & 100 & Paraná & 45 & $701 \mathrm{~A}$ & 100 & São Paulo \\
\hline 13 & 460 - Bt darmstadiensis & 100 & Paraná & 46 & 1658 & 100 & São Paulo \\
\hline 14 & T-10 Bt darmstadiensis & 77.9 & France & 47 & 1646 & 100 & São Paulo \\
\hline 15 & T-06 Bt entomocidus & 9.8 & France & 48 & $701 \mathrm{~B}$ & 100 & São Paulo \\
\hline 16 & T-24 Bt neoleonensis & 17.9 & France & 49 & 1648 & 100 & São Paulo \\
\hline 17 & T-27 Bt mexicanensis & 17 & France & 50 & 1438 & 100 & Sergipe \\
\hline 18 & T-23 Bt japonensis & 33.5 & France & 51 & $1438 \mathrm{H}$ & 100 & Sergipe \\
\hline 19 & T-16 Bt indiana & 12.2 & France & 52 & $1089 \mathrm{E}$ & 95.8 & Minas Gerais \\
\hline 20 & HD-73 Bt kurstaki & 2.7 & USA & 53 & $1091 \mathrm{H}$ & 95.8 & Minas Gerais \\
\hline 21 & HD-1 Bt kurstaki & 0 & USA & 54 & $1604 \mathrm{D}$ & 95.2 & Amazônia \\
\hline 22 & HD-12 Bt morrisoni & 28 & USA & 55 & 1605 & 95.2 & Amazônia \\
\hline 23 & HD-7 Bt dendrolimus & 5.4 & USA & 56 & 1657 & 100 & Amazônia \\
\hline 24 & HD-3 Bt finitimus & 5.2 & USA & 57 & 1656 & 100 & Alagoas \\
\hline 25 & HD-2 Bt thuringiensis & 37.8 & USA & 58 & $1603 B$ & 100 & Santa Catarina \\
\hline 26 & T-14 Bt israelensis & 0 & França & 59 & $1626 C$ & 97.6 & Maranhão \\
\hline 27 & $1119 C$ & 100 & Goiás & 60 & 702 & 97.6 & Mato Grosso \\
\hline 28 & $1124 \mathrm{E}$ & 100 & Goiás & 61 & 1354 & 100 & Minas Gerais \\
\hline 29 & $1131 \mathrm{~A}$ & 100 & Goiás & 62 & 1355SLO & 100 & Minas Gerais \\
\hline 30 & $1131 C$ & 100 & Goiás & 63 & $1357 \mathrm{E}$ & 100 & Paraná \\
\hline 31 & $1132 \mathrm{~A}$ & 100 & Goiás & 64 & 566 & 100 & Paraná \\
\hline 32 & $1132 C$ & 100 & Goiás & 65 & 1355LM & 100 & Minas Gerais \\
\hline 33 & $1138 \mathrm{G}$ & 100 & Goiás & & & & \\
\hline
\end{tabular}

\section{Results}

The number of fragments using REP primers varied from 1 to 4 per strain, with a total of 10 distinct fragments with the size ranging between 396 to 3.054 bp (Figure 1A). ERIC primers generated between 1 and 9 fragments per strain with a total of 19 distinct fragments ranging from 220 and $2.036 \mathrm{bp}$ (Figure 1B). However, BOX primer generated between 5 and 14 fragments, and a total of 26 distinct fragments between 200 and 3.054 bp (Figure 1C). BOX primers were the most informative among the three pairs of primers used followed by ERIC and REP primers, respectively.
Most of the isolates with subspecies identification showed a distinct profile for the three sequences analyzed (ERIC, REP, and BOX), however isolates 462A (Figure 1, well 5) and 474 (Figure 1, well 6) both subspecies B. thuringiensis subsp. galleriae showed the same bands for the three sequences analyzed (ERIC, REP and BOX), and the isolates $348 \mathrm{~L}$ (well 7, Figure 1) and HD29 (well 8, Figure 1) from the same subspecies showed different profiles. The same results were generated for the subspecies $B$. thuringiensis subsp. tolworthi where isolates 344 (well 9, Figure 1) and T09 (well 10, Figure 1) showed the same profile for REP and ERIC, and similar profile when BOX 


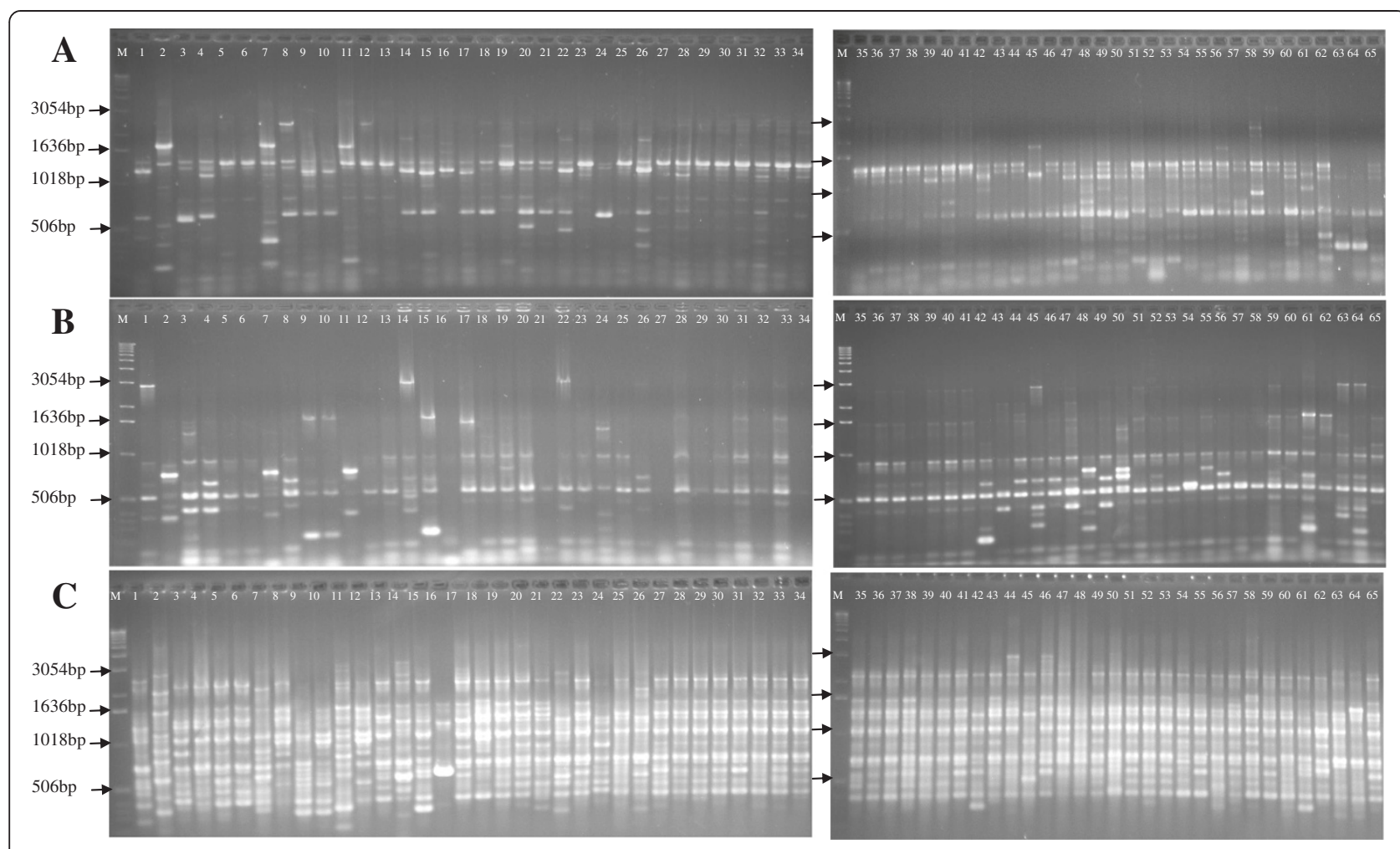

Figure 1 Rep-PCR fingerprint patterns of $\boldsymbol{B}$. thuringiensis and 65 references strains. (A) REP; (B) ERIC; (C) BOX and (M) 50 bp DNA ladder.

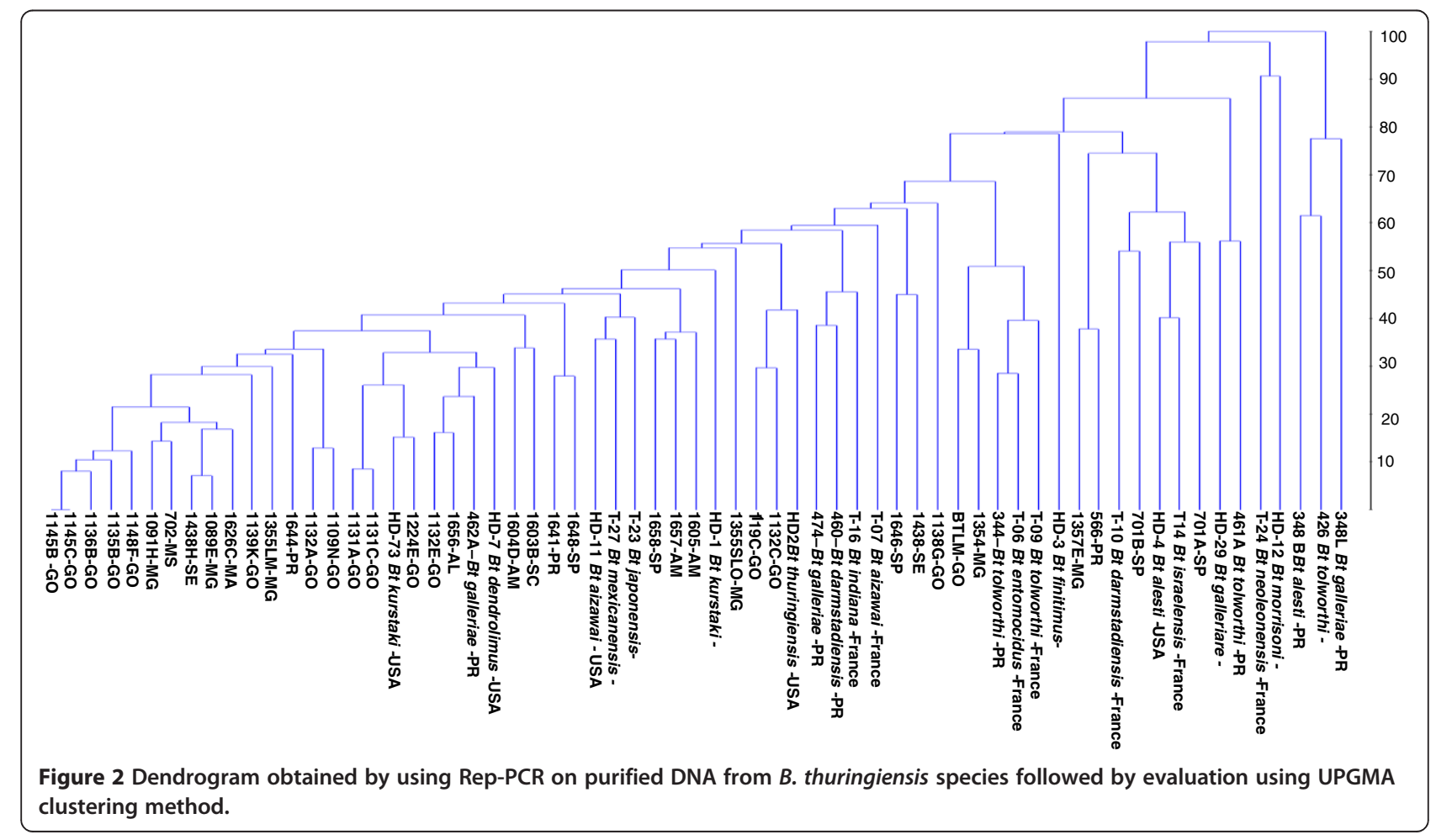


primers were used, however isolates 426 (Figure 1, well 11) and 461A (Figure 1, well 12) showed different profiles. B. thuringiensis subsp. alesti (well 1 and 2, F. 1), subsp. aizawai (well 2 and 4, Figure 1) and subsp. kurstaki (well 20 and 21, Figure 1) displayed different profiles for the 3 primer sequences used. Each one of all the other subspecies analyzed amplified a very specific fragment. Among the other 39 B. thuringiensis strains with no subspecies identification, those that were found in Goiás State showed similar profiles. However, isolates found in other Brazilian States showed different profiles.

A total of 55 fragments were generated when ERIC, REP and BOX primers were analyzed together and a dendrogram was generated when UPGMA grouping analysis was used (Figure 2), and considering $45 \%$ the average distance (cutting bridge) of the population 10 groups were formed, and group one consisted of $41,5 \%$ of the strains, including 2 USDA strains (HD73 Bt. thuringiensis subsp. kurstaki and HD7 B. thuringiensis subsp. dendrolimus), and one isolate from Embrapa (462A B. thuringiensis subsp. galleriae) all the other isolates are from Embrapa with no identification to subspecies. Although 33, 8\% of the remaining strains are distributed in the other groups, $24,6 \%$ of the strains analyzed were not in any group. Isolates $1145 \mathrm{~B}$ and $1145 \mathrm{C}$ showed the smallest genetic distance (0\%), however strains T24 (Bt neoleonensis) and HD12 (Bt morrisoni) were 90\% distant. The groups 3, 5, 6, 7 and 9 are only composed with strains from Embrapa Bt Collection, and group 5 was composed of strains sampled in Paraná State.

A genetic distance of $45 \%$ was detected in $53,2 \%$ of the strains from Embrapa, and they are in the same group, with $29,8 \%$ of the other strains are distributed in different groups, and $17,0 \%$ of the isolates appeared to be distinct. With the exception of 344 and T9 strains, both tolworthi subspecies, we can observe in the dendogram that $2 \mathrm{~B}$. thuringiensis subsp alesti, aizawai (2), darmstadiensis (2), kurstaki (2), galariae (4) and tolworth $i$ (4) showed genetic distance above $45 \%$.

\section{Discussion}

There are not much information published using rep-PCR to study the genetic diversity of $B$. thuringiensis isolates. Some papers describe the comparison of the amplification profiles by each primer pair (Cherif et al. 2003; Sauka et al., 2010), and some researchers discuss the grouping analysis using the individual data of each primer pair (Lima et al. 2002; Mehta et al. 2001). In our research the genetic diversity was studied using group analysis with data obtained when ERIC, REP and BOX primers were used altogether.

This research showed that when ERIC, REP and BOX are used together, the profiles generated are not related to the subspecies of the $B$. thuringiensis isolates, since there were bands in the profile very similar to some isolates of the same subspecie. The similarity of $B$. thuringiensis strains found in Goiás State may be related to the geographical localization (samples were harvested no more than $200 \mathrm{Km}$ apart), and all of them caused $100 \%$ in S. frugiperda larvae (Valicente and Barreto 2003). However, further studies are needed to confirm the hypothesis that similarity is related with geographic region. Isolates found in the same place may have a higher chance to harbor the same genetic material, however strains found in Goiás State were isolated in four different geographical regions. The remaining strains (collected in other states) represent a small sample of Bacillus thuringiensis to make a conclusion. Our results suggest that it is necessary a larger number of isolates but well distributed per region and with different mortality rates against a target insect, aiming to find a similarity between places or mortality. Strains with different mortality rates against $S$. frugiperda (Table 1) were found in the same group. Strains T09 and 344 subsp tolworthi were in the same group and the other subspecies did not show similarity for any group. B. thuringiensis isolates found in Goiás State showed higher similarity, however isolates found in other States showed a higher genetic distance in relation to the isolates found in Goiás State. Our results suggest that a genetic relationship among $B$. thuringiensis strains it is not defined only by the toxicity of the strain, but for many other reasons that some patterns may be revealed by REP-PCR technique are reproducible, and once these reactions were repeated to check the reproducibility of these fragments, and this reproducibility makes this technique more reliable than RAPD.

\section{Competing interest}

The authors declare that they have no competing interest.

\section{Authors' contributions}

FV collected all the Bt samples, analyzed the results and wrote the manuscript. RB carried out all the PCR reactions, evaluation and genetic diversity, wrote the manuscript and analyzed the results. Both authors read and approved the final manuscript.

\section{Acknowledgments}

The authors would like to thanks the University of Lavras and Embrapa Maize and Sorghum Research Center for supporting research projects.

\section{Author details}

'Department of Plant Biotechnology, Federal University of Lavras, Lavras, Minas Gerais, Brazil. ²Department of Biological control, Embrapa Maize and Sorghum research, Sete Lagoas, Minas Gerais, Brazil.

Received: 30 August 2013 Accepted: 30 October 2013

Published: 29 November 2013

\section{References}

Cherif A, Brusetti L, Borin S, Rizzi A, Boudabous A, Khyami-Horani H, Daffonchio D (2003) Genetic relationship in the Bacillus cereus group by rep-PCR fingerprinting and sequencing of a Bacillus anthracis-specific rep-PCR fragment. J Appl Microbiol 94:1108-1119

Cruz CD (2001) Programa genes: versão windows; aplicativo computacional em genética e estatística. UFV, Viçosa, MG, p 648 
Cruz CD, Carneiro PCS (2006) Modelos biométricos aplicados ao melhoramento genético: 2. ed. rev. MG: UFV, Viçosa

Efron B, Tibshirani R (1993) An introduction to the bootstrap. Chapman \& Hall, Boca Raton

Gilson E, Clément JM, Brutlag D, Hofnung M (1984) A family of dispersed repetitive extragenic palindromic DNA sequences in E. coli. EMBO J 3:1417-1421

Glare TR, O'Callaghan M (2000) Bacillus thuringiensis: biology. John Wiley \& Sons, Ltd., Ecology and Safety

Higgins CF, Ames GFL, Barnes WM, Clements JM, Hofnung M (1982) A novel intercistronic regulatory element of prokaryotic operons. Nature 298:760-762

Lima ASG, Guidelli AM, Abreu IL, Lemos MVF (2002) Identification of new isolates of Bacillus thuringiensis using rep-PCR products and $\delta$-endotoxin electron microscopy. Genetics and Mol Biolog 25:225-229

Louws FJ, Rademaker JLW, De Bruijn FJ (1999) The three Ds of PCR-based genomic analysis of phytobacteria: diversity, detection and disease diagnosis. Annu Rev Phytopathol 37:81-125

Martin B, Humbert O, Camara M, Guenzi E, Walker J, Mitchell T, Andrew P, Prudhomme M, Alloing G, Hakenbeck R, Morrison DA, Boulnois GJ, Claverys JP (1992) A highly conserved repeated DNA element located in the chromosome of streptococcus pneumonia. Nucleic Acids Res 20:3479-3483

Mehta A, Leite RP Jr, Rosato YB (2001) Assessment of the genetic diversity of Xylella fastidiosa isolated from citrus in Brazil by PCR-RFLP of the 165 rDNA and $165-235$ intergenic spacer and rep-PCR fingerprinting. Antonie van Leeuwenhoek 79:53-59

Miralles MP, Peres VJ (2004) Aislamiento y establecimento de una colección de Bacillus thuringiensis. In: Bravo A, Ceron J (eds) Bacillus thuringiensis em el control biológico. Bogotá, Colombia, pp 207-232

Rademaker JLW, De Bruijin FJ (1997) Characterization and classification of microbes by rep-PCR genomic fingerprinting and computer assisted patterns analysis. In: Caetano-Anollés G, Gresshoff, PM (eds) DNA Markes: Protocols, Applications and Overviews. Willey, New York, pp 151-171

Sauka DH, Basurto-Ríos RE, Ibarra JE, Benintende GB (2010) Characterization of an argentine isolate of Bacillus thuringiensis similar to the HD-1 strain. Neotrop Entomol 39:767-773

Shangkuan YH, Chang YH, Yang JF, Lin HC, Shaio MF (2001) Molecular characterization of Bacillus anthracis using multiplex PCR, ERIC-PCR and RAPD. Lett Appl Microbiol 32:139-145

Sharples GJ, Lloyd RG (1990) A novel repeated DNA sequence located in the intergenic regions of bacterial chromosomes. Nucleic Acids Res 18:6503-6508

Shuhaimi M, Ali AM, Saleh NM, Yazid AM (2001) Utilisation of eterobacterial repetitive intergenic consensus (ERIC) sequence-based PCR to fingerprint the genomes of Bifidobacterium isolates and other probiotic bacteria. Biotechnol Lett 23:731-736

Stern MJ, Ames GF, Smith NH, Robinson EC, Higgins CF (1984) Repetitive extragenic palindromic sequences: a major component of the bacterial genome. Cell 37:1015-1026

Valicente FH, Barreto MR (2003) Bacillus thuringiensis survey in Brazil: geographical distribution and insecticidal activity against Spodoptera frugiperda (J.E. Smith) (Lepidoptera: Noctuidae). Neotrop Entomol 32:639-644

Valicente FH, Fonseca MM (2004) Susceptibilidade da lagarta-do-cartucho do milho, Spodoptera frugiperda, a diferentes isolados de Bacillus thuringiensis. Revista Brasileira de Milho e Sorgo 3:21-29

Versalovic J, Koeuth T, Lupski JR (1991) Distribution of repetitive DNA sequences in eubacteria and application to fingerprinting of bacterial genomes. Nucleic Acids Res 19:6823-6831

Versalovic J, Schneider M, De Bruijn FJ, Lupski JR (1994) Genomic fingerprinting of bacteria using repetitive sequence-based polymerase chain reaction. Methods in Molecular and Cellular Biology 5:25-40
Vilas-Boas G, Sanchis V, Lereclus D, Lemos MVF, Bourguet D (2002) Genetic differentiation between sympatric populations of Bacillus cereus and Bacillus thuringiensis. Appl Environ Microbiol 68:1414-1424

Yamamoto T, Dean DH (2000) Insecticidal proteins produced by bacteria pathogenic to agriculturas pests. In: Charles JF, Delécluse A, Nielsen-Le Roux C (eds) Entomopathogenic bacteria: from laboratory to field application. Kluwer Academic, Dordrecht, pp 81-100

doi:10.1186/2193-1801-2-641

Cite this article as: da Silva and Valicente: Molecular characterization of Bacillus thuringiensis using rep-PCR. SpringerPlus 2013 2:641.

\section{Submit your manuscript to a SpringerOpen ${ }^{\circ}$ journal and benefit from:}

- Convenient online submission

- Rigorous peer review

- Immediate publication on acceptance

- Open access: articles freely available online

- High visibility within the field

- Retaining the copyright to your article

Submit your next manuscript at $\gg$ springeropen.com 